https://helda.helsinki.fi

\title{
Luther Reception in Asia and Africa
}

\section{Ruokanen, Miikka}

2013

Ruokanen, M 2013 , ' Luther Reception in Asia and Africa ' , Lutherjahrbuch : Organ der internationalen Lutherforschung , no. 80 , pp. 279-283 .

http://hdl.handle.net/10138/156311

publishedVersion

Downloaded from Helda, University of Helsinki institutional repository.

This is an electronic reprint of the original article.

This reprint may differ from the original in pagination and typographic detail.

Please cite the original version. 
tification and original sin as faith issues. This affords him the opportunity to interpret the Fall-story in Gen 3 in less misogynist and sexphobic ways than one might expect from a medieval exegete. Identifying the first disobedience as a matter of the will when the human heart lost trust in God, and not as the culpa of the body or the first woman, Luther grieves over the post-Fall distorted (mis)awareness that makes human beings experience as shameful their most divine, original state: nudity and sexuality. In gender relations and "in the nude " human beings know what it means to live as simul iustus et peccator. Third, future re-exploration of Luther's interpretation of the OT as a source for his theology will do well to embrace the input of gender studies and Jewish scholarship and to address issues pertaining to unnecessarily male-centric and Christ-centric readings of the Hebrew texts.

\section{Luther Reception in Asia and Africa}

Seminar Leader: Miikka Ruokanen

Reporter: Miikka Ruokanen

The participants of this seminar were: Michael Albrecht, Armin Buchholz, Chen Yongtao, Jin-Seop Eom, Paulos Huang, Kathryn Kleinhans, Gregory Miller, Kenneth Mtata, Miikka Ruokanen, Carolyn Schneider, William Schumacher, Jane Strohl, Wang Aiming and Karl Weber. Half of the fourteen participants of the seminar presented a paper. The sessions were filled with lively, sometimes even enthusiastic discussions.

Jin-Seop Eom gave a paper on
"Luther in Korea." Paulos Huang and Miikka Ruokanen both offered separate papers on "Luther and China." Armin Buchholz spoke on "Luther in the Chinese Context of Taiwan. Michael Albrecht presented a paper on "Confessional Lutheranism Encounters Pentecostalism in India." Kenneth Mtata's presentation was on "The Holy Spirit and Luther Reception in Africa. Jane Strohl spoke on "The Lutheran Church in Rwanda.“ 
I The Potential of Luther's Theology for Asia

The person and theology of Martin Luther in many ways inspire many non-Western Christians. Luther is seen as the founding father of Protestantism at large, not only of Lutheranism; he belongs to all the Protestants, not only the Lutherans. Consequently, his theology is somewhat influential in all Protestant churches, not only in the Lutheran churches.

The "four solae" of Luther's theology are highly appreciated, for instance, in Korea and China. They are a healthy counterbalance against the persistent anthropocentrism of Asian religious thinking, against the trends of the socalled prosperity gospel, and against all kinds of legalistic tendencies so typical in many Asian churches. The Asian Christians willingly refer to Luther when defending the doctrine of grace, the idea of the justification of the sinner by grace and through faith alone. They also regard Luther's distinction between law and gospel as crucially important.

Jin-Seop Eom summarized the relevance of Luther's theology for East Asia:
Luther's theology of the cross can be a corrective to the theology of prosperity; his principles of sola fide and sola gratia to Calvinistic legalism; his understanding of a Christian being simultaneously justified and sinner to the Methodist notion of perfectionist sanctification; his principle of sola scriptura to the Full Gospel Church's enthusiasm and mysticism; his law and gospel dialectic to the fundamentalist view of Scripture in general; his ecclesiology and sacramental theology to the low view of church and sacraments; his evangelical liturgy to simplistic worship; his doctrine of two kingdoms to the mixture of religion and politics, etc.

Many Asian theologians see an especially strong point of contact between Luther's theological paradoxes and the East Asian view of reality. East Asian philosophies and religions emphasize the harmony of the opposites, one reality with two mutually indispensable and inseparable aspects, such as the simultaneity of yin and yang. Similarly, the backbone of Luther's theology consists of the idea of simul, the simultaneity of the opposites. Luther and the East may meet as they reflect on the meaning of reality.

In spite of the great potential of Luther's theology for Asia, it is a fact that Luther is overshadowed by Jean Calvin and even by John Wesley in most Asian churches. 
Their theology has been influenced more by the Calvinistic/Reformed tradition than the Lutheran theological heritage. In addition, Asian Lutheran churches normally are very small and often divided among themselves to several small independent synods - this weakens the impact of Lutheran theology.

\section{Luther on Chinese Soil}

The Chinese Protestant church, the fastest growing church in the world, identifies herself as a "postdenominational " church. After the Communist revolution, all of the about 70 Protestant denominations were compelled to become united in the I950's. Still today, this church is exploring and seeking her true theological nature; in this process the theologies of both Luther and Calvin seem to play an important role.

It seems that Calvin is dominating the theological development of the non-registered church communities (the so-called house churches), whereas in the registered churches, under the leadership of the Three-Self Patriotic Movement and the China Christian Council, Luther and Calvin seem to have an equally important influence. The strict discipline and stern atmosphere of Calvinism, creating something completely "other" in regard to the current fluctuating society, has a special appeal to Christian intellectuals of non-registered churches.

Interestingly, not only the theological heritage of Luther but also his personality has inspired Asian Christians. Korean Protestants, who are predominantly Calvinists, see Luther as a symbolic figure expressing the power of reforming various spheres of life. They also appreciate Luther who "prayed three hours a day." The Bible-loving Chinese Christians see Luther as a model of a good pastor and preacher who concentrated both his theological thinking and his pastoral work on the truthful exposition of Scripture. Luther is seen as "a man of the Bible " emphasizing the authority of God's word. Because many non-Western churches lack trained pastors, the role of lay leadership is crucially important. Consequently, Luther's teaching on the common ministry of all believers is highly appreciated.

In today's secular academic circles of Mainland China, Luther has a high regard as model of a "revolutionary " modern man. In many textbooks, he is included among 
the one hundred most influential persons of human history. In spite of Luther's failure to support the German peasants' revolution, he is seen as a reformer who served the interests of the people, opposing the feudal "tyranny " of the pope, the emperor, and the privileged nobility. He worked for the freedom and equality of all people and created a popular education system.

Among Luther's works, his treatise The Freedom of a Christian is most loved by both Chinese scholars and Christians. They feel that the idea of maximal inner personal freedom combined with complete loyalty in the service of the people expresses a core concept of traditional Chinese ethics. As China became a leading economic power in the world, secular Chinese scholars are deeply interested in the connection between the development of Western capitalism and Protestant ethics; Max Weber is carefully studied in Chinese universities.

\section{India and Africa}

Some of the theological concerns in the Indian and African contexts are similar to those arising in the East Asian context, but there are differences, too. In India, the Lutheran identity is not very strong: Many Lutherans have a "dual membership " in the sense that they attend the Lutheran service on Sunday morning and then go to Pentecostal meetings afterwards. Many Lutheran pastors in India have never even seen Luther's Small Catechism! Well over half of the Christians in India are Pentecostals, a situation which challenges all other denominations. Indian Pentecostals respect Luther as a significant Christian leader, though they hardly understand the core of his theology.

Similar to the Indian situation, understanding and experiencing the reality of the Holy Spirit plays a central role in the growth of Christianity in Africa. Due to the influence of the context, i.e. traditional African religions and culture, pneumatology and healing are top issues of African Christian spirituality.

A leading Lutheran theologian, Manas Buthelezi is engaging Reformation tradition from the African perspective trying to reformulate it. Emphasis of the Holy Spirit is combined with insights from liberation theology. As a Lutheran theologian, Buthelezi uses the Bible as the basis of discussion; while as a contextual theologian, he begins 
with his personal experience and the experiences of his church members. He is unwilling to relinquish the ministry of the Holy Spirit to the Pentecostals, he reclaims it as a genuinely Lutheran heritage. In doing so, he needs to recover teachings on sanctification which he thinks have been marginalized because of the unbalanced appropriation of justification.

\section{Luther Research in Non- Western Countries}

In spite of the deep interest in Luther among the non-Western Protestants, scholarly Luther research can - according to our knowledge - only be found in Korea, Japan, China, and some Latin American countries (though we had no representatives from Japan or Latin America in this seminar). The most important challenge here is the language barrier: the inability to read Luther in original German and Latin. Most of the research is based on English translations. Also, access to interna- tional research materials is very limited.

The Lutheran Confessions, parts of Luther's works, as well as some well-known Western pieces of research on Luther have been translated into Korean, Chinese, and Japanese languages. For instance, a new Chinese series of Luther's Works has begun to appear in Shanghai, but even this is based on the American edition of Luther's works. In China, secular scholars in universities do research on Luther, whereas in theological seminaries, there is an interest but a lack of capacity to study Luther. In Korea, I72 Master's theses during the period of 200I-20IO were related to Martin Luther. An ecumenical Korean Luther Study Society was founded in 2008.

It is obvious that a further development of academic scholarship in Luther research as well as Reformation studies in general is urgently needed in non-Western countries, where already two thirds of all the Christians of the world are living. 